POLLACK PERIODICA

An International Journal for Engineering and Information Sciences

DOI: $10.1556 / 606.2020 .15 .3 .20$

Vol. 15, No. 3, pp. 208-219 (2020)

www.akademiai.com

\title{
OVERVIEW AND ANALYSIS OF THE OVERHEATING EFFECT IN MODERN SUDANESE BUILDINGS
}

\author{
${ }^{1}$ Suha I. A. ALI ${ }^{*}{ }^{2}$ Zsuzsa SZALAY \\ ${ }^{1,2}$ Department of Construction Materials and Technologies, Faculty of Civil Engineering \\ Budapest University of Technology and Economics, Múegyetem rkp. 3., H-1111 Budapest \\ Hungary, ${ }^{1}$ suha8896@hotmail.com, ${ }^{2}$ szalay.zsuzsa@epito.bme.hu
}

Received 23 December 2019; accepted 24 April 2020

\begin{abstract}
Sudan is suffering from harsh summers, but most of the modern buildings in urban areas are not compatible with the recent and future climate phenomena. Application of cooling devices is relatively expensive and therefore beyond reach. The main objective of this research is to give an overview on the overheating problem and the thermal comfort in buildings. A dynamic energy simulation has been performed for a selected case study using Design Builder Code. The results show that the share of discomfort hours for a typical modern building is $78 \%$ and $33 \%$ above $26{ }^{\circ} \mathrm{C}$ and $32{ }^{\circ} \mathrm{C}$ per year, respectively, but after using a combination of different ventilation, shading and building materials options the discomfort hours can be reduced to $77 \%$ and $26 \%$, respectively.
\end{abstract}

Keywords: Climate change, Overheating, Thermal comfort, Dynamic energy simulation, Sudan

\section{Introduction}

With climate change, overheating is likely to occur more frequently [1]. According to the Stern Report on climate change, overheating problems need to be highlighted and tackled now [2]. The primary function of buildings and building services engineering is to create and maintain a comfortable environment for people. Overheating is increasing during warm weather in buildings without air-conditioning, especially in homes in temperate climates where the retention of winter heat has been the major focus of thermal design [3]-[5].

\footnotetext{
${ }^{*}$ Corresponding Author
} 
Thermal comfort is the point of satisfaction with the thermal environment, i.e. when the great majority of people are not feeling either too hot or too cold. Thermal discomfort is where people start to feel uncomfortable, i.e. they are feeling hot or cold, but they are not experiencing any health effects [6]. There are many factors that affect thermal comfort. For overheating discomfort, temperature is probably the primary factor but there are other factors that affect the feeling of comfort or discomfort in both hot and cold conditions. The other factors are humidity, air movement, radiation and radiation asymmetry [7], [8].

There is no internationally accepted definition of 'overheating' because it depends on local climatic conditions. The WHO guidance on thermal comfort states that temperatures above $24{ }^{\circ} \mathrm{C}$ cause discomfort in temperate zones [9]. Factors like the rate of increase in temperature, the temperature reached, the length of time for which the temperature stays high and individual tolerance are all important factors [10].

As a result of climate change, the summer overheating phenomenon occurs in different climate zones. The effect is the worst in the hot arid climate zone because it is very far from the comfort zone on the psychrometric chart [11] and it is difficult to achieve the comfort level by applying simple solutions [12], [13]. Also, there are gaps in the knowledge on the thermal performance of buildings in developing countries. The main objective of this paper is to analyze the overheating level in modern Sudanese buildings and study the effect of applying passive techniques, such as shading, ventilation and choice of building materials using dynamic building energy simulation.

\section{Methodology}

The thermal performance of a building and the internal comfort can be assessed using dynamic building simulation. For dynamic simulation, a lot of data are required as location, weather, building geometry and building materials, etc., which are described in the following sections.

\subsection{Description of the case study}

A first building typology matrix for Sudan has been compiled by Ali and Szalay [14]. In this paper, one type from the typology is selected, which is representative of modern buildings in a warm semi-arid climate zone. The building is a single-family house with a floor area of $96 \mathrm{~m}^{2}$ (Fig. 1). There were no architectural plans available, but a common arrangement and typical dimensions were assumed based on expert estimations. The building has a single floor with two bedrooms, kitchen, living area, toilet and bathroom. There is a wall made out of bricks surrounding the building, which is very typical due to security and privacy reasons.

\subsection{Location and weather file (Sudan, Khartoum)}

Sudan is located in North-East Africa. Sudan is classified into three climatic zones (Zone I: warm desert climate, Zone II: warm semi-arid climate and Zone III: tropical savanna climate) as it is shown in Fig. 2 [15], [16]. Sudan's weather is characterized by 
three seasons: the hot season from March-May (summer), the wet rainy season between June and October (autumn) and the dry season from November until February (winter).
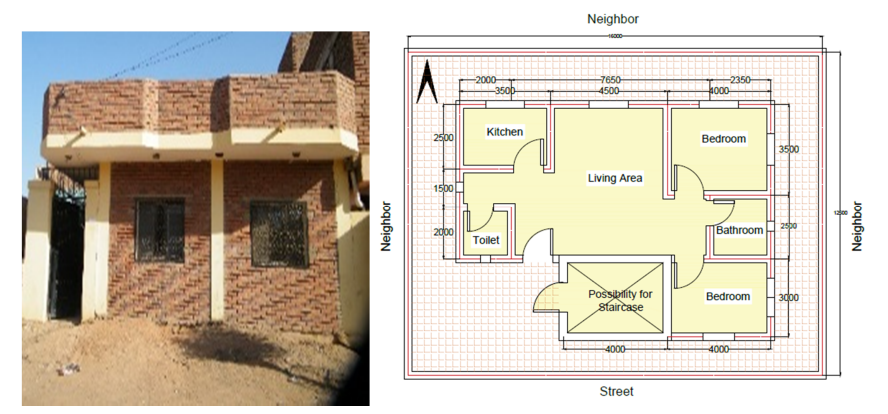

Fig. 1. Plan and photo of the building

The northern part of Sudan (zone I) has a harsh climate compared to the other regions. Here summer temperatures exceed $43.3{ }^{\circ} \mathrm{C}$ in the desert zones and rainfall is negligible, except in the center, where rainfall is common between June and September. Zone II has moderate summer and winter temperatures, high rainfall and relative humidity values, because it is close to the tropical savannah region [17], [18].

The greatest amount of solar radiation in Sudan is between 15 and 35 latitude north. Wind speed and direction vary with seasons. In winter, the wind speed ranges between $0.54 \mathrm{~m} / \mathrm{s}$ to $1.54 \mathrm{~m} / \mathrm{s}$ in N and NW direction, while in the summer season winds are in the direction of NW to SW.

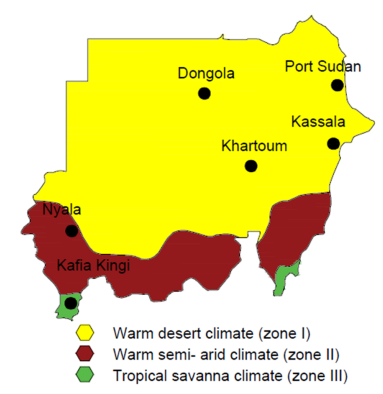

Fig. 2. Sudan climate zones (Source: S. I. A. Ali on the basis of Koppen, and Sudan Meteorological Authority (SMA) [16], [15])

The case study is located in the capital city Khartoum, with latitude N15.550 ${ }^{\circ}$, longitude E32.530 ${ }^{\circ}$, altitude $366 \mathrm{~m}$ and climate zone $1 \mathrm{~B}$ according to the Meteonorm database [18]. In Khartoum, the average annual temperature is about $26.7^{\circ} \mathrm{C}$; and the annual rainfall is about $254 \mathrm{~mm}$. Energy simulation tools need hourly ambient conditions (temperature, humidity, wind velocity, solar radiation, etc.) at the building location. This information is available in weather files. For this simulation, the weather file from Meteonorm was used [18]. 


\subsection{Building energy simulation tool}

The simulation was performed with Design Builder Code, v6. Design Builder provides a range of environmental performance data like energy consumption, comfort conditions, maximum summertime temperatures and Heating, Ventilation and Air Conditioning (HVAC) component sizes [19].

\subsection{Base case model}

As the first step for the simulation process, a base case model was created that is typical for Sudanese buildings and can be compared with different design alternatives. The base case has solid brick walls with concrete slab, natural ventilation and no shading system.

Orientation. The typical orientation of the building allowing maximum natural ventilation and daylight is shown in Fig. 1. In selecting suitable building orientation in hot dry regions, reduction of the internal daytime temperatures must be the main objective, and thus minimization of solar load is a primary concern [20].

Zoning. Zones are used in thermal simulations to divide the building into separate areas with different energy/thermal characteristics [19]. As the selected case study is a small single-storey building where internal doors would be frequently left open, a single zone is used in the calculations. Additional thermal mass was included in the simulation using hanging partitions.

Building components. It is necessary to have construction details, for instance the thickness and thermo-physical properties of materials used in each layer of the building envelope (Table I). The floor consists of 4 layers, which are plain concrete, sand layer, cement mortar and ceramic tiles. External walls are $0.3 \mathrm{~m}$ solid brick walls with mortar and plaster layer inside and outside the wall, while internal walls and partitions are 20 $\mathrm{cm}$ thick and have a loadbearing function with a similar composition to external walls. The flat roof is most common in the urban parts of Sudan. Usually a mixture of crush bricks, sand and stabilizer is applied on the top of the flat roof as a kind of waterproofing, and this was modeled as a lightweight plaster material in Design Builder. This case study has a reinforced concrete flat roof with a $2 \mathrm{~cm}$ plaster layer in the top and $1 \mathrm{~cm}$ base plaster on the bottom of the roof (Fig. 3). The thermal properties were taken from the database of Design Builder. Thermal bridges were neglected in this study.

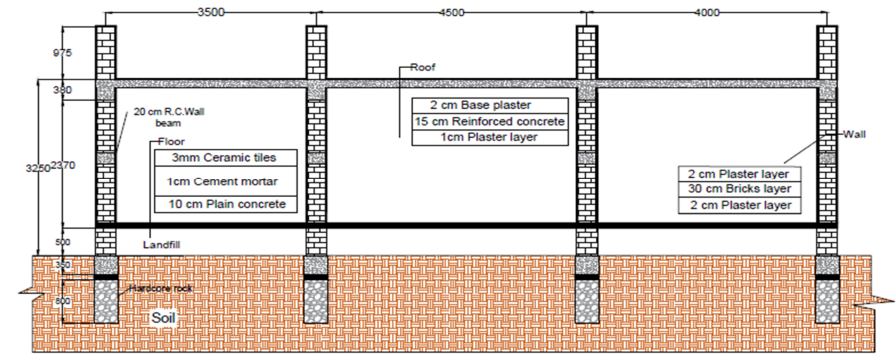

Fig. 3. Construction details (cross-section) 
Table I

Description of the wall and roof buildings materials options

\begin{tabular}{|c|c|c|c|}
\hline \multicolumn{2}{|r|}{ Wall } & \multicolumn{2}{|c|}{ Roof } \\
\hline 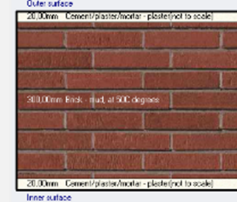 & 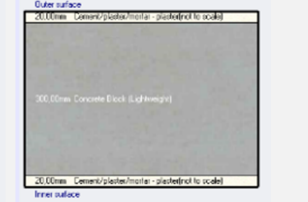 & & 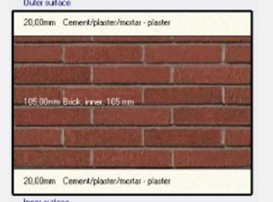 \\
\hline $\begin{array}{l}\underline{\text { Solid Bricks }} \\
\frac{\text { (base case) }}{2 \mathrm{~cm} \text { plaster }} \\
30 \mathrm{~cm} \text { red bricks } \\
2 \mathrm{~cm} \text { plaster } \\
U=1.729 \mathrm{~W} / \mathrm{m}^{2} \mathrm{~K}\end{array}$ & $\begin{array}{l}\text { Lightweight Conc. B. } \\
2 \mathrm{~cm} \text { plaster } \\
30 \mathrm{~cm} \text { concrete block } \\
2 \mathrm{~cm} \text { plaster } \\
U=0.537 \mathrm{~W} / \mathrm{m}^{2} \mathrm{~K}\end{array}$ & $\begin{array}{l}\text { R.C. Slab (base } \\
\frac{\text { case) }}{2 \mathrm{~cm} \text { L.W plaster }} \\
15 \mathrm{~cm} \text { R.C Slab } \\
1 \mathrm{~cm} \text { plaster } \\
U=2.787 \mathrm{~W} / \mathrm{m}^{2} \mathrm{~K}\end{array}$ & $\begin{array}{l}\frac{\text { Jack Arch Roof }}{2 \mathrm{~cm} \text { plaster }} \\
10 \mathrm{~cm} \text { inner brick } \\
2 \mathrm{~cm} \text { plaster } \\
U=2.264 \mathrm{~W} / \mathrm{m}^{2} \mathrm{~K}\end{array}$ \\
\hline 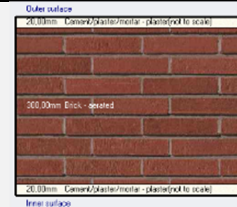 & 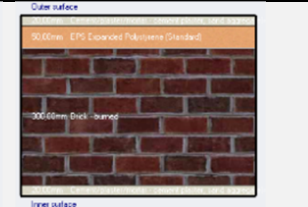 & 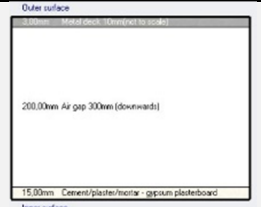 & Ounesules \\
\hline $\begin{array}{l}\text { Hollow R Bricks } \\
2 \mathrm{~cm} \text { plaster } \\
30 \mathrm{~cm} \text { hollow } \\
\text { bricks } \\
2 \mathrm{~cm} \text { plaster } \\
U=0.779 \mathrm{~W} / \mathrm{m}^{2} \mathrm{~K}\end{array}$ & $\begin{array}{l}\text { Solid Bricks }+5 \mathrm{~cm} \mathrm{Ins} \text {. } \\
1 \mathrm{~cm} \text { plaster } \\
5 \mathrm{~cm} \text { EPS } \\
30 \mathrm{~cm} \text { red bricks } \\
2 \mathrm{~cm} \text { plaster } \\
U=0.547 \mathrm{~W} / \mathrm{m}^{2} \mathrm{~K}\end{array}$ & $\begin{array}{l}\text { CISs + Air gap } \\
3 \mathrm{~mm} \text { metal sheet } \\
20 \mathrm{~cm} \text { air gap } \\
1,5 \mathrm{~cm} \quad \text { gypsum } \\
\text { board } \\
U=2.156 \mathrm{~W} / \mathrm{m}^{2} \mathrm{~K}\end{array}$ & $\begin{array}{l}\text { R.C. Slab }+5 \mathrm{~cm} \text { Ins. } \\
2 \mathrm{~cm} \text { light W. plaster } \\
5 \mathrm{~cm} \text { EPS } \\
15 \mathrm{~cm} \text { R.C Slab } \\
1 \mathrm{~cm} \text { plaster } \\
U=0.622 \mathrm{~W} / \mathrm{m}^{2} \mathrm{~K}\end{array}$ \\
\hline 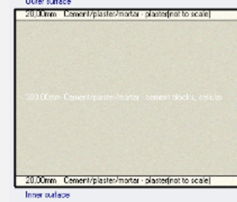 & 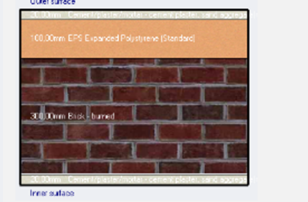 & 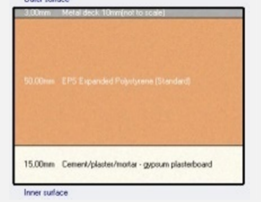 & 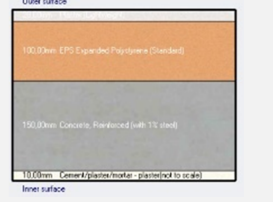 \\
\hline $\begin{array}{l}\frac{\text { Cement Block }}{2 \mathrm{~cm} \text { plaster }} \\
30 \mathrm{~cm} \quad \text { cement } \\
\text { blocks } \\
2 \mathrm{~cm} \text { plaster } \\
U=0.838 \mathrm{~W} / \mathrm{m}^{2} \mathrm{~K}\end{array}$ & $\begin{array}{l}\underline{\text { Solid Bricks }+10 \mathrm{~cm}} \\
\underline{\text { Ins. }} \\
1 \mathrm{~cm} \text { plaster } \\
10 \mathrm{~cm} \text { EPS } \\
30 \mathrm{~cm} \text { red bricks } \\
2 \mathrm{~cm} \text { plaster } \\
U=0.325 \mathrm{~W} / \mathrm{m}^{2} \mathrm{~K}\end{array}$ & $\begin{array}{l}\frac{\text { CISs + EPS Roof }}{3 \mathrm{~mm} \text { metal sheet }} \\
5 \mathrm{~cm} \mathrm{EPS} \\
1,5 \mathrm{~cm} \text { gypsum } \\
\text { board } \\
U=0.674 \mathrm{~W} / \mathrm{m}^{2} \mathrm{~K}\end{array}$ & $\begin{array}{l}\text { R.C. Slab }+10 \mathrm{~cm} \text { Ins } \\
2 \mathrm{~cm} \text { light } \mathrm{W} . \text { plaster } \\
5 \mathrm{~cm} \text { EPS } \\
15 \mathrm{~cm} \text { R.C Slab } \\
1 \mathrm{~cm} \text { plaster } \\
U=0.35 \mathrm{~W} / \mathrm{m}^{2} \mathrm{~K}\end{array}$ \\
\hline
\end{tabular}

Openings (Doors and Windows) Doors are usually made of wood or aluminum, while windows have single glazing with a wooden, aluminum or metallic frame.

Shading. In Sudan, usually there are two types of shading: a permanent one, which is aluminum fencing for windows (mostly for security purposes) and curtains. Due to the high solar altitude, roofs with an overhang also shade the windows. For the base case, no shading was applied.

Usage of building. The hourly schedules of occupancy, lighting, equipment, thermostat set-point, and HVAC operation are required for the simulation. Internal gains 
are calculated according to the occupants' density, activity, and equipment. Sudanese single family houses are normally occupied by an average of 5 persons [21], so the occupant density is 0.05 person $/ \mathrm{m}^{2}$. Metabolic activity is assumed as light manual work, $150 \mathrm{~W}$ household equipment is calculated as the absolute zone power and $24{ }^{\circ} \mathrm{C}$ is the indoor temperature ventilation set-point.

Ventilation and infiltration. There are two general approaches to model natural ventilation and infiltration in Design Builder: 'scheduled', where fixed air change rates are set manually by users or 'calculated', where natural ventilation and infiltration rates are modeled based on window opening, cracks, buoyancy and wind-driven pressure differences. In the case study, the calculated model option is used for more accuracy. For infiltration, 'poor airtightness' from the crack template of Design Builder was assumed according to Sudanese building envelope characteristics. Due to the high cost of mechanical ventilation installations, natural ventilation is mainly used in Sudanese buildings. Simple fans are used in some parts of the buildings. Windows were assumed to be open if the internal temperature is above $24{ }^{\circ} \mathrm{C}$ and the external temperature is lower than the internal temperature. External doors were assumed to be closed 24 hours a day.

Cooling system. In Sudan, mechanical cooling is usually not applied due to the high cost. Sometimes simple air conditioners are used. Here, no cooling system was assumed.

\subsection{Applied options}

In order to analyze the effect of certain parameters on the thermal comfort, different options for ventilation, shading and building materials were examined. For natural ventilation, the different tested options are temperature controlled ventilation, no ventilation and constant ventilation option (Table II). For shading, closed weave inside and outside, and cantilever of $0.5 \mathrm{~m}$ and $1 \mathrm{~m}$ from the flat slab have been applied (Table II). The options for the wall are solid bricks, hollow red bricks, cement block, lightweight concrete block and solid bricks +5 or $10 \mathrm{~cm}$ polystyrene insulation. The options for roof are concrete slab, jack arch roof, corrugated iron sheets with or without insulation and concrete slab with 5 or $10 \mathrm{~cm}$ polystyrene insulation (Table I).

\section{Results and discussion}

\subsection{Base case results}

The annual, seasonal and weekly temperatures have been extracted and compared for the base case and the different options. Fig. 4 shows the annual internal Operative $(\mathrm{Op})$ and the Outside Dry-Bulb (ODB) temperatures for the base case. Generally, there is a big difference between the day and night temperatures. During the summer hot season, the maximum ODB temperature difference between day and night is $16{ }^{\circ} \mathrm{C}$, while the minimum is $7{ }^{\circ} \mathrm{C}$. The maximum range for the ODB and Op temperatures are between 34-46 and $26-38{ }^{\circ} \mathrm{C}$ during the daytime, and $17-24$ and $23-30{ }^{\circ} \mathrm{C}$ during the night, respectively. 
Table II

Description of the ventilation and shading options

\begin{tabular}{|c|c|c|c|c|c|}
\hline \multicolumn{3}{|c|}{ Ventilation } & \multicolumn{3}{|c|}{ Shading } \\
\hline \multirow{2}{*}{ 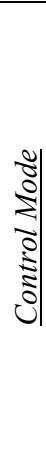 } & $\begin{array}{l}\text { Temperature (base case) } \\
\text { Windows and doors are } \\
\text { opened if Tzone }>\text { Tout } \\
\text { and Tzone }>\text { Tset } \\
\text { Tset }=24{ }^{\circ} \mathrm{C}\end{array}$ & $\begin{array}{l}\text { Constant } \\
\text { Windows } \\
\text { and doors } \\
\text { are open all } \\
\text { the time. }\end{array}$ & \multirow{2}{*}{ 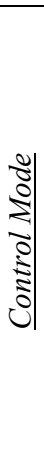 } & $\begin{array}{l}\text { Drapes- close weave light } \\
\text { inside: } \\
\text { Outdoor air temperature }+ \\
\text { Horizontal solar } \\
\text { Solar setpoint }=150\left(\mathrm{~W} / \mathrm{m}^{2}\right) \\
\text { Tset }=24^{\circ} \mathrm{C}\end{array}$ & $\begin{array}{l}n \\
0 \\
0 \\
\vdots \\
\vdots \\
\vdots \\
0 \\
0 \\
0 \\
0\end{array}$ \\
\hline & & $\begin{array}{l}\frac{N o}{\text { Ventilation }} \\
\text { Windows } \\
\text { and doors } \\
\text { are closed } \\
\text { at all times. }\end{array}$ & & $\begin{array}{l}\text { Drapes- close weave light } \\
\frac{\text { outside }}{\text { Outdoor air temperature }+} \\
\text { Horizontal solar } \\
\text { Solar setpoint }=150\left(\mathrm{~W} / \mathrm{m}^{2}\right) \\
\text { Outside air temperatre } \\
\text { setpoint }=24^{\circ} \mathrm{C}\end{array}$ & 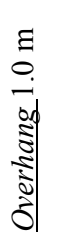 \\
\hline
\end{tabular}

In the wet autumn, the maximum difference between day and night ODB temperatures is $13{ }^{\circ} \mathrm{C}$, while the minimum is $3{ }^{\circ} \mathrm{C}$. The maximum range for the ODB and $\mathrm{Op}$ temperatures are between $35-44$ and $29-38{ }^{\circ} \mathrm{C}$ during the daytime, and 21-26 and $26-30{ }^{\circ} \mathrm{C}$ during the night. In the dry winter season, the maximum ODB temperature difference between day and night is $15^{\circ} \mathrm{C}$, while the minimum is $10{ }^{\circ} \mathrm{C}$. The maximum range for the $\mathrm{ODB}$ and $\mathrm{Op}$ temperatures are between $30-39$ and $24-33{ }^{\circ} \mathrm{C}$ during the daytime and $24-14$ and $22-32^{\circ} \mathrm{C}$ during the night.

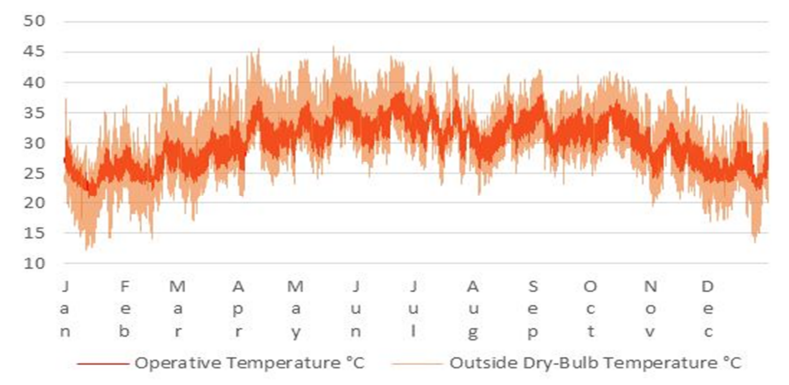

Fig. 4. Annual operative and outside dry-bulb temperatures $\left({ }^{\circ} \mathrm{C}\right)$ for the base case

In order to compare the total discomfort hours between the different seasons, the hottest week in the hot, wet and dry season was selected. As of now there is no standard discomfort level for the hot arid climate or especially for Sudan. According to the discomfort baseline, the number of Discomfort Hours (DH) above $26{ }^{\circ} \mathrm{C}$, which is a standard value in Europe was counted, and also 28, 30 and $32{ }^{\circ} \mathrm{C}$ Op and ODB temperatures. Fig. 5 illustrates the indoor and outdoor total DH percentage for the hottest week in the summer, autumn and winter seasons. In the summer week, the operative temperature is always above $32{ }^{\circ} \mathrm{C}$, while for the ODB all the hours are above 
$28{ }^{\circ} \mathrm{C}$, and 95 and $81 \%$ of the hours are above 30 and $32{ }^{\circ} \mathrm{C}$, respectively. The autumn week is even hotter, $89 \%$ of the hours are above $32{ }^{\circ} \mathrm{C}$ for the ODB. In the winter season, the percentage of discomfort hours is much lower than in the summer and autumn, only $13 \%$ of the hours are above $26{ }^{\circ} \mathrm{C}$ for the operative temperature.

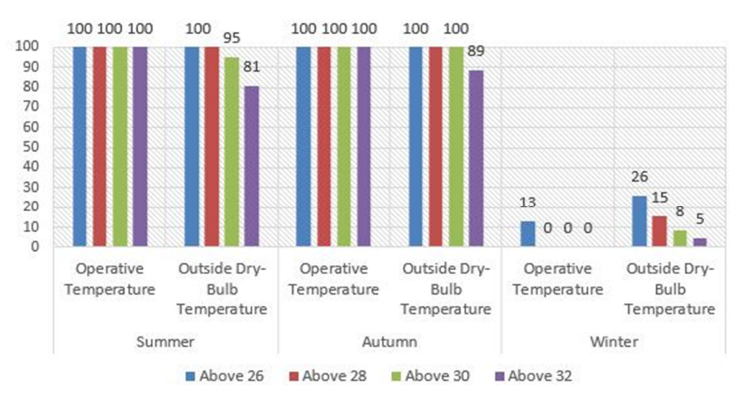

Fig. 5. Percent of hours above a certain temperature limit for the summer, autumn and winter design week

\subsection{Different options results}

As it is shown in Fig. 6 and Table III the annual discomfort hours (above 26, 28, 30 and $32{ }^{\circ} \mathrm{C}$ ) are calculated for the different ventilation, shading, and material options. In the calculations, only one parameter was changed at a time compared to the base case.

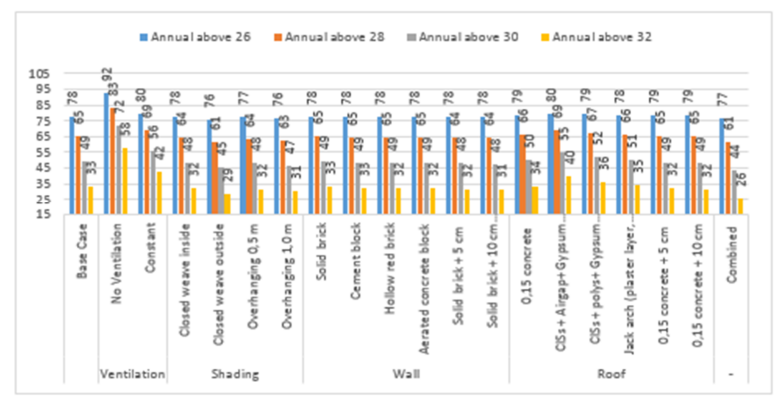

Fig. 6. Percent of the annual discomfort hours for the different selected options compared to the total hours of the year

In the ventilation options, the lowest discomfort hours are registered for the temperature control model option, which represents the base case, with 6806 hours above $26{ }^{\circ} \mathrm{C}$, while both the no ventilation option and the constant ventilation have higher values. For the shading options, DH results for the closed weave outside are better than the other shading options, but applying an overhang shading has the benefit of allowing more daylight into the room.

Regarding the applied material options, there is no big change in the discomfort values for the walling and roofing material. Applying an insulation layer of $10 \mathrm{~cm}$ to the 
base case wall and roof showed discomfort hours of about 5609 and 5696 above $30{ }^{\circ} \mathrm{C}$ and 6798 and 6892 above $26^{\circ} \mathrm{C}$, respectively.

\section{Table III}

Total discomfort hours per year for the different studied options

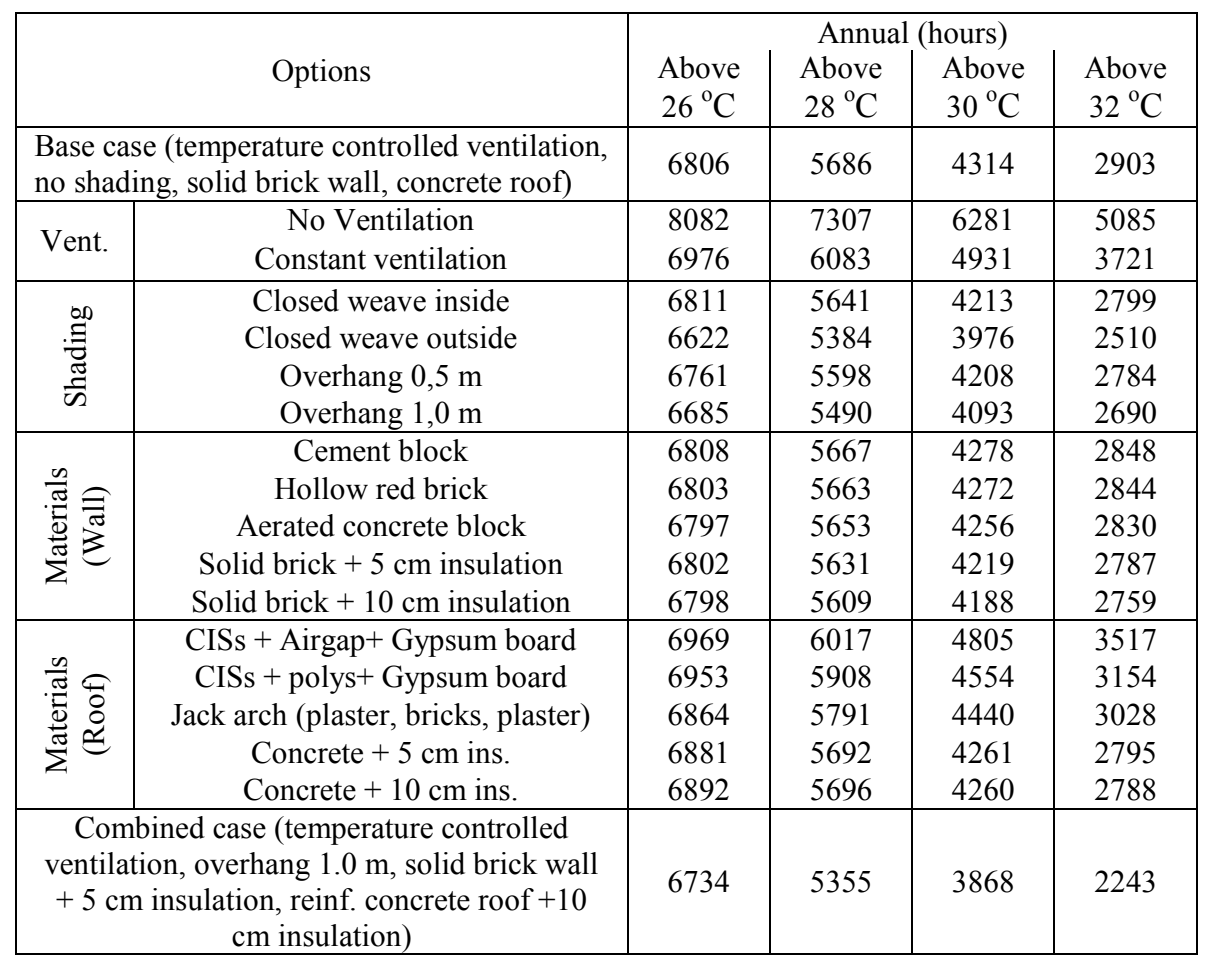

Finally, in order to decrease the discomfort hour values, a combination of different options is used (Table III). The combined model uses the temperature control ventilation option with a $1 \mathrm{~m}$ overhang for shading and an insulation layer of $5 \mathrm{~cm}$ for the solid brick wall and $10 \mathrm{~cm}$ for the concrete roof slab. After applying these, the annual discomfort hours decreased by 660 hours above $32{ }^{\circ} \mathrm{C}$, that represent $23 \%$ improvement compared to the base case (Fig. 6).

\subsection{Temperature in the different seasons}

For more details through the different seasons, a temperature comparison between the base case and the combined model was added. In the summer, there is some difference for the operative temperature between the base case and the modified combined case, the highest temperature for the base case is $40.3{ }^{\circ} \mathrm{C}$ while for the combined case $37.04{ }^{\circ} \mathrm{C}$ (Fig. 7a).

During the autumn, a reduction in operative temperature can be observed throughout the whole week period. The highest temperature registered for the base case is $38.35{ }^{\circ} \mathrm{C}$ 
and $36.07{ }^{\circ} \mathrm{C}$ for the combined case (Fig. 7b). In the winter season, there is no big difference in the operative temperatures between the base and combined case, so the highest operative temperature was $27.83{ }^{\circ} \mathrm{C}$ for the base case and $26.32{ }^{\circ} \mathrm{C}$ for the combined case (Fig. 7c).

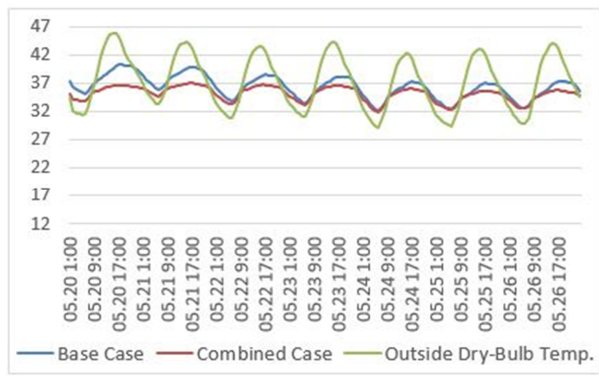

a)

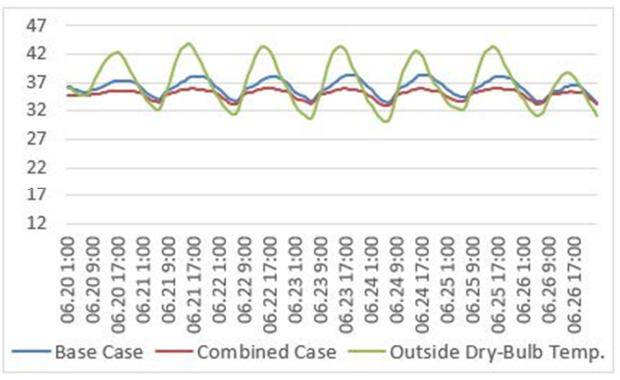

b)

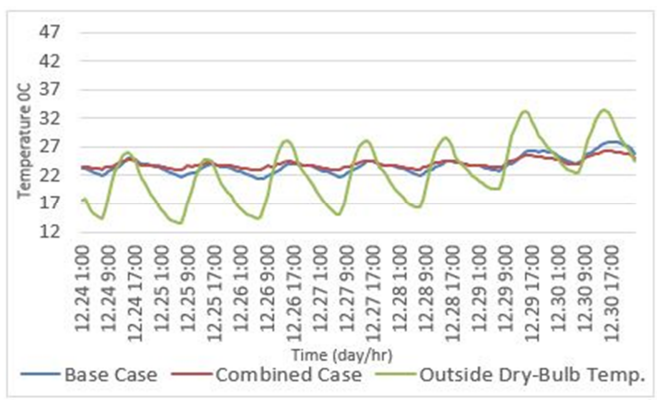

c)

Fig. 7. Hourly (design week) operative temperatures for the base case and combined case during a) summer b) autumn c) winter

Fig. 8 illustrates the difference in temperatures between the base case and the combined case during the summer, autumn and winter seasons. The maximum temperature decrease occurs during the summer by $3.66{ }^{\circ} \mathrm{C}$, followed by the autumn season where the difference in the operative temperature for the combined case was $2.53{ }^{\circ} \mathrm{C}$. In the winter season, the difference is less and temperatures in the combined case are slightly higher than in the base case but still in the comfort range.

\section{Conclusion}

In this paper, the internal temperatures in a typical modern Sudanese building were analyzed. Based on the dynamic simulation modeling the following can be concluded:

$>$ In the base case the simulation results showed that $78 \%$ and $33 \%$ of the year is above $26{ }^{\circ} \mathrm{C}$ and $32{ }^{\circ} \mathrm{C}$, respectively; 
$>$ Most of the comfort period is in the winter dry season (Nov to Feb), while the rest of the year (March to Oct) was in the discomfort level;

$>$ If no natural ventilation is applied when the outside temperatures are lower than inside, the annual discomfort hours increase by $14 \%$ and $25 \%$ above $26{ }^{\circ} \mathrm{C}$ and $32{ }^{\circ} \mathrm{C}$ over the year, respectively;

$>$ It is difficult to achieve $100 \%$ comfort level for the base case without using a mechanical ventilation or cooling system, but by using a combination of different passive solutions, an improvement of $10 \%$ above $30{ }^{\circ} \mathrm{C}$ and $23 \%$ above $32{ }^{\circ} \mathrm{C}$ compared to the base case can be achieved;

$>$ There is no specific benchmark for the discomfort level in the hot arid climate zone. In this research the temperatures above $26,28,30$ and $32{ }^{\circ} \mathrm{C}$ were checked;

$>$ Only the internal operative temperatures were analyzed as a first indicator of overheating. As thermal comfort is a function of various parameters, further research will focus on complex thermal indices.

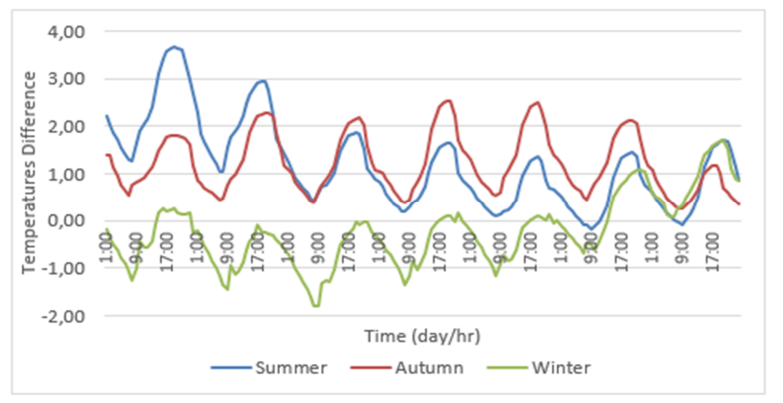

Fig. 8. Difference in the internal operative temperatures between the combined and the base case for the summer, autumn and winter design week

\section{Acknowledgements}

'Optimization of buildings and building elements from life cycle and building physics perspective based on complex numeric modeling" (Project FK 128663) has been implemented with the support provided from the National Research, Development and Innovation Fund of Hungary, financed under the FK_18 funding scheme. This research was also supported by the FIKP grant of EMMI in the frame of the Water sciences \& Disaster Prevention research area of the Budapest University of Technology and Economics FIKP-VÍZ.

\section{Open Access statement}

This is an open-access article distributed under the terms of the Creative Commons Attribution 4.0 International License (https://creativecommons.org/licenses/by/4.0/), which permits unrestricted use, distribution, and reproduction in any medium, provided 
the original author and source are credited, a link to the CC License is provided, and changes - if any - are indicated. (SID_1)

\section{References}

[1] Global Warming of $1.5^{\circ} \mathrm{C}$, An IPCC Special Report on the impacts of global warming of $1.5^{\circ} \mathrm{C}$ above pre-industrial levels and related global greenhouse gas emission pathways, in the context of strengthening the global response to the threat of climate change, sustainable development, and efforts to eradicate poverty, IPCC, 2018.

[2] Stern N. The economics of climate change, The Stern review, Cambridge University, 2007.

[3] Race G. How to manage overheating in buildings: a practical guide to improving summertime comfort in buildings. The Chartered Institution of Building Services Engineers, London, 2010.

[4] Lomas K. J., Porritt S.M. Overheating in buildings: Lessons from research, Building Research \& Information, Vol. 45, No. 1-2, 2017, pp. 1-18

[5] Rapp D. Assessing climate change temperatures, solar radiation, and heat balance, Praxis Publishing, Chichester, UK, 2013.

[6] TM52: The limits of thermal comfort: avoiding overheating in European buildings, The Chartered Institution of Building Services Engineers, London, 2013.

[7] Robertson G. Passive design toolkit, City of Vancouver, 2009.

[8] Albdour M. S., Baranyai B. Numerical evaluation of outdoor thermal comfort and weather parameters in summertime at Széchenyi square, Pollack Periodica, Vol. 14, No. 2, 2019, pp. 131-142.

[9] Indoor environment: Health aspects of air quality, thermal environment, light and noise, WHO, 1990.

[10] Dengel A., Swainson M., Ormandy D., Ezratty V. Overheating in dwellings guidance document, The BRE Centre for Resilience, 2011.

[11] ASHRAE Standard 55-2010, Thermal environmental conditions for human occupancy, 2010.

[12] Osman M. M., Sevinc H. Adaptation of climate-responsive building design strategies and resilience to climate change in the hot/arid region of Khartoum, Sudan, Sustainable Cities and Society, Vol. 47, 2019, Paper No. 101429.

[13] Szkordilisz F, Kiss M. Passive cooling potential of alley trees and their impact on indoor comfort, Pollack Periodica, Vol. 11, No. 1, 2016, pp. 101-112.

[14] Ali S. I. A., Szalay Zs. Towards developing a building typology for Sudan, IOP Conference Series: Earth and Environmental Science, Vol. 323, Paper No. 012012.

[15] Sudan Meteorological Authority, Maximum Temperature Forcast, Sudan, 2018.

[16] Köppen Climate Classification, Sudan map of Köppen climate classification, 2019.

[17] World Weather and Climate, Sudan Metrological Authority World Weather Information Service, 2019

[18] Meteonorm v7.1, weather data of Khartoum, 2019.

[19] DesignBuilder, https://designbuilder.co.uk/helpv6.0, (last visited 2 March 2020).

[20] Ahmed M. H. A. Solutions to low income urban housing problems in the Sudan, $P h D$ Thesis, University of Sheffield, England, 1978.

[21] Central Bureau of Statistics Census, Sudan, 2008. 